\title{
ADAKAH SISTEM PASAR BEBAS ISLAMI?
}

\author{
Addiarrahman \\ UIN Sunan Kalijaga Yogyakarta \\ Email:addiarrahman@gmail.com
}

\begin{abstract}
Abstrak
Kajian ini berupaya mengelaborasi pemikiran Ibn Taimiyah tentang mekanisme pasar, namun bukan dalam upaya membentuk klaim atau penegasan bahwa sebelum Adam Smith, konsep mekanisme pasar telah dicetuskan oleh Ibn Taimiyah dan pemikir lainnya. Sekalipun hal itu adalah fakta sejarah, namun alasan yang menjadi inspirasi bagi tulisan ini adalah untuk membantah anggapan sementara pihak yang menyatakan bahwa konsep ekonomi Islam, berpihak pada pasar bebas (liberal), atau mirip dengan welfare state dari kaum sosialis.
\end{abstract}

Kata Kunci: Mekanisme Pasar, Pasar Bebas, Walfare State

\section{Pendahuluan}

Pemikiran ekonomi yang dihasilkan oleh para pemikir muslim mulai dikaji kembali semenjak gagasan ekonomi Islam berkembang. Hal ini tidak lepas dari tesis the great gap yang dilontarkan Joseph A. Schumpeter. Ia menandaskan, setelah runtuhnya peradaban Yunani-Romawi, terjadi kekosongan karya pemikiran ekonomi selama \pm 500 tahun dan karya pemikir skolastik St. Thomas Aquinas, Summa Theologica (ditulis 12651274) merupakan karya awal yang mengisi kekosongan tersebut. Summa disejajarkan Schumpeter sebagai Cathedral of Charters dalam sejarah arsitektur(Joseph A. Schumpeter, 1954). Dengan demikian, Schumpeter menisbikan warisan pemikiran muslim tentang ekonomi. Sekalipun cukup didukung oleh banyak pemikir barat (Arif Hoetoro, 2007) dan mendapat kritik dari sebagaian kecil pemikir barat dan Islam (S.M. Ghanzafar, 2003), namun, tesis Schumpeter ini sangat berpengaruh bagi perkembangan 
ilmu ekonomi, misalnya euro-centrism ilmu ekonomi. Dampaknya, ketika berbicara ekonomi Islam, gagasan yang dikembangkan sering kali beranjak dari teori ekonomi konvensional; atau sebatas klaim bahwa jauh sebelum Adam Smith, pemikir muslim sudah menggagas konsep mekanisme pasar, teori permintaan dan penawaran, keuangan publik, hak kepemilikan serta lain sebagainya. Lebih dari itu, doktrin ekonomi St. Thomas Aquinas juga disinyalir memplagiasi ide-ide pemikiran ekonomi dari pemikir muslim. Klaim seperti ini sekalipun cukup baik untuk membentuk mental keilmuan, namun di sisi lain, justeru menjadi boomerang. Mengapa umat muslim, lebih sering mengklaim hasil pemikiran tokoh 'Barat' dari pada menghasilkan atau mengembangkannya sendiri? Apakah mitos tertutupnya pintu ijtihad cukup ampuh dijadikan alasan untuk menutupi kelemahan tersebut?

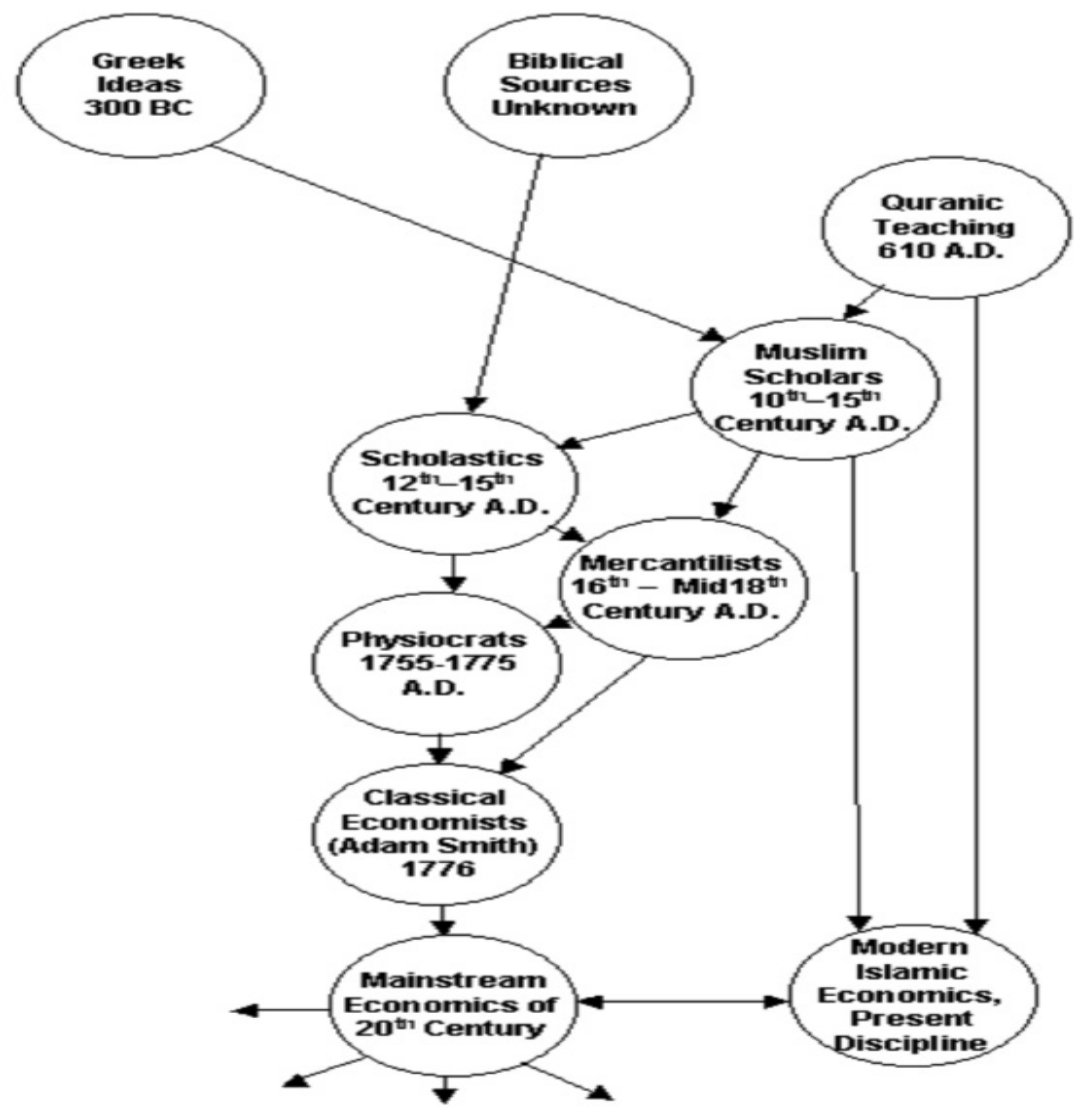


Ibn Taimiyah adalah seorang tokoh yang hidup pada saat dunia Islam tengah dikepung oleh tiga marabahaya: pasukan Salib dari Eropa, tentara Mongol dari Timur, dan disintegrasi politik dalam tubuh umat Islam (Salim, 1999). Namun, ide pemikirannya banyak menjadi inspirasi bagi pembaharuan Islam. Termasuk dalam hal ini adalah pemikiran ekonomi, misalnya pemikirannya mengenai mekanisme pasar yang di dalamnya juga berkaitan dengan peran negara dalam mengontrol pasar. Kajian ini berupaya mengelaborasi pemikiran Ibn Taimiyah tersebut, namun bukan dalam upaya membentuk klaim atau penegasan bahwa sebelum Adam Smith, konsep mekanisme pasar telah dicetuskan oleh Ibn Taimiyah dan pemikir lainnya. Sekalipun hal itu adalah fakta sejarah, namun alasan yang menjadi inspirasi bagi tulisan ini adalah untuk membantah anggapan sementara pihak yang menyatakan bahwa konsep ekonomi Islam, berpihak pada pasar bebas (liberal), atau mirip dengan welfare state dari kaum sosialis. Bahkan Arskal Salim menolak simplifikas Islahi, M. Nejatullah Siddiqie, Muhammad al-Mubarak yang menyatakan intervensi negara merupakan unsur pokok dan terpenting dalam pemikiran Ibn Taimiyah, bahkan sebanding dengan kecenderungan sistem ekonomi welfare state (Salim, 1999). Islahi menulis, "Ibn Taimiyah's concept of the state and its role in economic life is most aptly compared to the welfare state in the modern sense (Islahi, 1988)

Anggapan ini seringkali disematkan kepada pemikiran Ibn Taimiyah mengenai mekanisme pasar. Asumsi bahwa perbedaan utamanya adalah paradigma dan sumber pemikiran di mana Islam dengan paradigmanya merujuk al-Qur'an dan al-Sunnah, sedangkan Adam Smith (Barat) bertolak dari paradima liberalisme-individualisme, atau Karl Marx dengan konsep materialisme historis, agaknya tidak dapat diterima begitu saja. Karena merujuk pada era keemasan Islam, tidak satu pun fakta sejarah yang mendukung asumsi tersebut. Oleh sebab itu, pemikiran Ibn Taimiyah mengenai mekanisme pasar, dalam tulisan ini, diposisikan pada konteks historisnya, sehingga tampak bahwa Ibn Taimiyah ingin meletakkan fungsi pemerintah pada pra-konsepsi yang dibangunya mengenai penegakkan syari'at Islam. Ini tidak terlepas dari pandangan politiknya yang menegaskan wajibnya kepemimpinan, kerena amar ma'ruf nahi 
munkar tidak akan terlaksana tanpa adanya kekuasaan (quwwah) dan pemerintah (imarah). Bahkan Ia menyatakan:

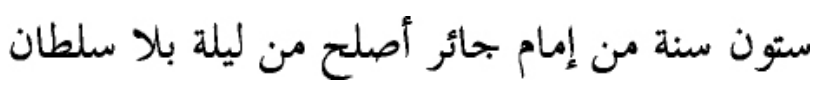

"Enam puluh tahun dari kehidupan pemimpin yang zalim lebih baik dari pada satu malam tanpa adanya kepemimpinan" (Ibn Taimiyah, 1983)

\section{الله ينصر اللولة العادلة وإن كانت كافة ولا ينصر اللولة الظالمة ولو كانت}

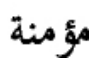

"Allah akan menolong suatu negeri yang 'Adil sekalipun dihuni oleh orangorang kafir, dan tidak akan menolong negeri yang zolim sekalipun mereka semua adalah orang-orang yang beriman." (Ibn Taimiyah, 1980)

Dua karya utama Ibn Taimiyah yang menjadi rujukan dalam tulisan ini adalah al-Hisbah fi al-Islam, dalam edisi Inggris berjudul Public Duties in Islam, diterjemah oleh Muhtar Holland dan dalam edisi Indonesia berjudul Tugas Negara Menurut Islam, diterjemahkan oleh Arif Maftuhin Dzofir dari edisi inggris, dan al-Siyasah al-Syar'iyah fi Islah al-Ra'i wa al-Ra'iyyah, edisi Indonesia diterjemahkan oleh Rofi' al-Munawwar berjudul Siyasah Syar'iyah Etika Politik Islam.

\section{Biografi Singkat Ibn Taimiyah}

Ibn Taimiyah lahir di Harran pada tanggal 22 Januari 1263 M (10 Rabiul Awal 661 H). Nama lengkapnya adalah Taqī al-Dīn Ahmad bin 'Abd alHalīm bin 'Abd Salam bin Taimiyah. Ia wafat pada tahun 728 H/1328 M di Damaskus. Terkenal sebagai pemikir dalam mazhab Hanbali yang banyak melakukan pemurnian ajaran Islam yang dianggap bid'ah, bertentangan dengan al-Qur'an dan al-Sunnah. Ayahnya 'Abd al-Halim, pamannya Fakhr al-Din dan kakeknya Majd al-Din dikenal sebagai ahli dalam mazhab Hanbali dan penulis buku. Pada tahun 1270, Harran diserobot tentara Mongol dan keluarga besar Taimiyah hijrah ke Damaskus (Salim, 1999). 
Sebagaimana telah disebutkan, Ibn Taimiyah hidup pada masa kegentingan politik melanda dunia Islam. Ia sedikit diuntungkan dengan kekuatan Dinasti Mamluk yang mampu bertahan dari serangan tentara Mongol di bawah kendali Chengis Khan dan selanjutnya diteruskan oleh keturunannya, Arghun (penganti Ahmad atau Tagudar), dan Hulaghu pendiri Dinasti Ilkhan yang menghancurkan Baghdad. Pada masa kekuasaan Mongol, peraturan Yassa menjadi hukum resmi yang ditentang keras oleh Ibn Taimiyah. Karen Armstrong menulis, He [Ibn Taimiyah] declared that even though the Mongols had converted to Islam, they were in fact infidels and apostates, because they had promulgated the Yasa instead of the Shariah (Armstrong, 2002). Di sisi lain, tekanan dari tentara Salib di Syria dan Palestina memperburuk kondisi di tengah disintegrasi politik internal dunia Islam.

Dikatakan diuntungkan karena Syria berada dalam lindungan Dinasti Mamluk di Mesir karena dinasti ini adalah salahsatu dinasti yang gagal diruntuhkan tentara Mongol (Dinasti lainnya adalah Sriwijaya, Martin Stuart-Fox, 2003). Dinasti Mamluk adalah dinasti yang didirikan oleh bekas budak militer. Mereka pada mulanya berasal dari budakbudak belian berbangsa Turki, Kurdi, Armenia, dan Sirkassia. Reuben Levy sebagaimana dikutip oleh Arskal Salim menulis: ketentaraan pada saat itu dibedakan menjadi tiga macam: (1) tentara yang terdaftar atau mustakhdimun; (2) tentara budak atau mamluk, yang bila menunjukkan kecakapan dan keberanian luar biasa dalam karirnya akan dimerdekakan oleh tuannya; dan (3) tentara yang tidak masuk ke dalam kedua kategori tersebut (Salim, 1999).

Selain sistem politik dan pemerintahan, kehidupan sosal ekonomi pada masa Dinasti Mamluk juga mempengaruhi pemikiran Ibn Taimiyah. Struktur masyarakat dinasti Mamluk, sebagaimana dikutip Islahi dari Sayuti, terbagi menjadi tiga kelas, yaitu: (1) para Mamluk dan keturunan tentara budak yang merupakan elit penguasa; (2) pada ahl al-Imamah, atau para pegawai pemerintah, seperti sekretaris, hakim, ulama, juru tulis dan lain sebagainya; adapun kelas terakhir (3) diduduki oleh para buruh, pedagang, petani, tukang, dan lainnya. Dari sekian banyak kelompok pada kelas ketiga ini, para petani merupakan kelompok yang mengalami nasib 
terburuk karena dibebani pajak yang sangat banyak (Islahi, 1988).

Pertanian merupakan prioritas utama pada masa dinasti Mamluk dan menjadi sumber pokok kesejahteraan. Di samping itu, bidang-bidang industry juga dikembangkan, seperti tekstil, metal, gula, kayu, ukiran, dan pembuatan kapal. Aktifitas perdagangan cukup pesat. Jalur-jalur perdagangan dunia ramai dilalui, namun jalur samudera India, Laut Merah, hingga tiba di Sungai Nil dan terus ke kota Iskandariah menjadi rute utama karena lebih aman dari ancaman bangsa Mongol. Untuk menjaga aktifitas perdagangan, raja Mamluk membentuk lembaga hisbah (Islahi, 1988; Salim, 1999). Lembaga ini, menurut Jonathan P. Berkey, tidak tepat bila dianggap diderivasi dari konsep "market inspector" (Greek: agoronomos, Latin: argumentum) atau pandangan yang menganggap lembaga hisba hanya berperan sebagai badan pengawas pasar (sûq). Lebih dari itu, ia melingkupi "all those things that constitute the entirety of social life." (Jonathan P Berkey, 2004)

Berkaitan dengan aspek moneter, Ibn Taimiyah mencatat bahwa di Damaskus mata uang dinar dan dirham sama-sama digunakan sebagai alat pertukaran barang dan jasa. Namun kemudian peredaran mata uang dirham lebih meluas, sehingga berakibat nilai tukar mata uang dirham mengalami penurunan. Situasi ini diperparah oleh kebijakan Sultan Kitbugha (1294-1296) yang berencana mencetak uang fulus dalam jumlah banyak dengan nominal yang lebih besar dari nilai intrinsik yang dikandungnya (Jhon L. Meloy, 2003; Warren C. Schultz, 2004).

Dengan kompleksitas kehidupan politik, sosial, ekonomi, hukum yang dihadapi, dan karakter Ibn Taimiyah yang tegas dan sangat berprinsip dalam menegakkan syari'at Islam, ia empat kali pernah keluar masuk penjara. Namun, daya intelektualnya sama sekali tidak melemah. Ia terus menulis dan menulis, bahkan pada saat alat tulisnya disita, ia tetap menulis dengan menggunakan arang, hingga akhirnya seluruh bahan bacaan dan tulisan-tulisannya dirampas. Saat itulah ia berhenti menulis dan tidak lama kemudian menghembuskan nafas terakhir. Para peneliti memperkirakan ada sekitar 300-500 karya Ibn Taimiyah. Di antara karya-karyanya adalah: Majmu' Fatawa Syaikh al-Islam, Iqtitif alSirat al-Mustaqim wa Mukhtalafah Ashab al-Jahir, al-Sarim al Maslul'Ula Syatim 
al-Rasul, al-Jawab al-Salih liman Baddala Din al-Masih, al-Jawami' fi al-Siyasah al-Ilahiyah wa al-Ayat al-Nabawiyah, al-Rass 'Ala al-Mantiqiin, al-Siyasah alSyar'iyyah fi Islah al Ra'i wa al-Ra'iyah, Fatawa Ibnu Taimiyah, al-Hisbah fi al-Islam, dan lain sebagainya ( Amalia, 2010).

\section{Mekanisme Pasar dan Sistem Pasar Bebas}

Kedua terma di atas (mekanisme pasar dan sistem pasar bebas) seringkali dipahami secara bias. Satu sisi, mekanisme pasar sering disimplifikasi sebagai sistem pasar bebas, dan sistem pasar bebas dianggap sebagai mekanisme pasar itu sendiri. Bahkan sementara pihak ada yang secara berlebihan menganggap sistem pasar bebas sebagai sunnatullah. Padahal, kedua terma tersebut memiliki perbedaan yang sangat signifikan, baik dari secara defenitif maupun konseptual. Bagian ini meletakkan kedua istilah tersebut pada porsinya, sembari mengelaborasi pemikiran Ibn Taimiyah tentang mekanisme pasar dan aspek lain yang berkaitan di dalamnya.

\section{Mekanisme Pasar}

Pasar, secara sederhana dapat dipahami sebagai bertemunya permintaan dan penawaran. Dari terjadilah pertukaran barang dan jasa. Dari situ, harga terbentuk dan lazim disebut sebagai titik equilibrium, yaitu titik keseimbangan harga dan kuantitas dari permintaan dan penawaran (Joseph E. Stiglitz Carl E. Walsh, 2005). Terbentuknya harga dari proses tersebut disebut sebagai mekanisme pasar (Pratama Rahardja \& Mandala Manurung, 1999). Secara umum, dengan demikian pasar atau mekanisme pasar adalah interaksi sosial yang dilakukan manusia dalam rangka memenuhi kebutuhannya, yaitu dengan melakukan permintaan dan penawaran terhadap suatu barang.

Kurva 1. Keseimbangan Pasar 


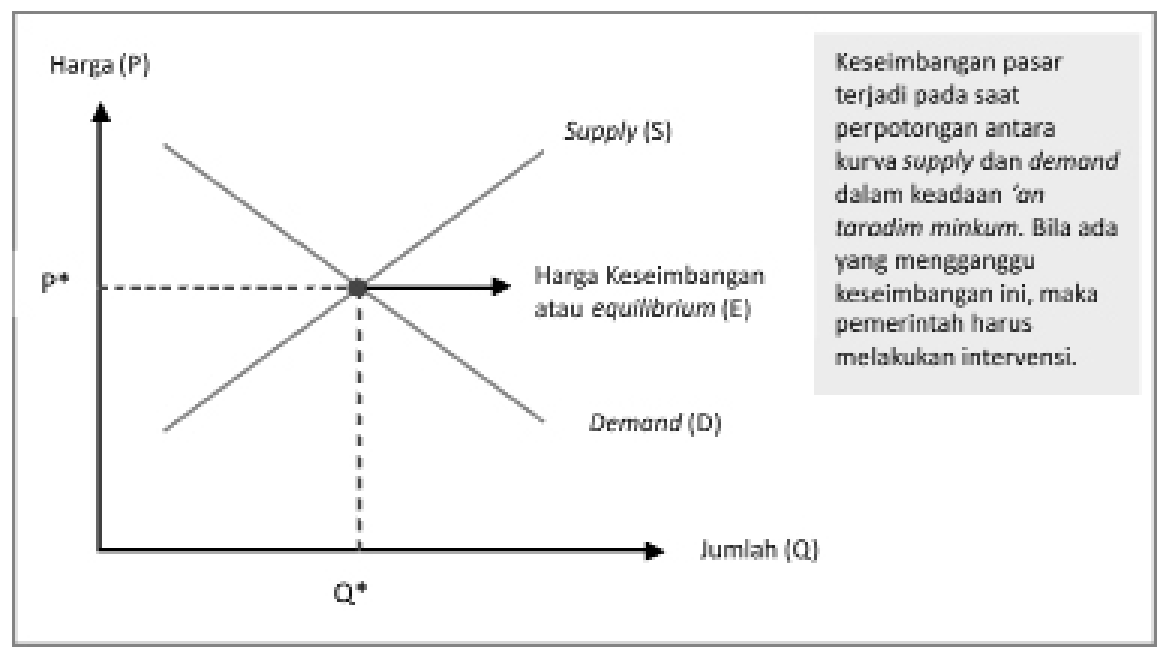

Ibn Taimiyah dan pemikir Islam lainnya (seperti Ibn Khaldun) memberikan pandangan yang sangat penting untuk memahami mekanisme pasar. Ibn Taimiyah menulis "Naik turunnya harga tak selalu berkaitan dengan kezhaliman (zulm) yang dilakukan seseorang. Sesekali alasannya adalah adanya kekurangan dalam produksi atau penurunan impor dari barang-barang yang diminta. Jadi, jika membutuhkan peringkat jumlah barang, sementara kemampuannya menurun, harga dengan sendirinya naik. Di sisi lain, jika kemampuan penyediaan barang meningkat dan permintaannya menurun, harga akan turun. Kelangkaan dan kelimpahan tak mesti diakibatkan oleh perbuatan seseorang. Bisa saja disebabkan oleh ketidakadilan. Maha besar Allah yang menciptakan kemauan pada hati manusia." (Ibn Taimiyah, 1993 dalam Amalia, 2010)

Penekanan Ibn Taimiyah terhadap kondisi zulm, kekurangan, dan keadilan, dapat dipahami sebagai upaya dia dalam memahami struktur masyarakat pada saat itu. Ibn Taimiyah berupaya tidak menutupi faktor alamiah terlebih mengenyampingkan adanya perbuatan zulm atau ketidakadilan. Ini memperlihatkan bahwa untuk terciptanya suatu mekanisme yang fair, maka kealamiahan mekanisme pasar tidak boleh dirusak oleh penyimpangan, seperti manipulasi, penimbunan barang, dan lain sebagainya. Pandangan serupa juga ditulis oleh Ibn Khaldun dalam bukunya Muqaddimah. Ia menulis: "ketika barang-barang yang tersedia sedikit, harga-harga akan naik. Namun, bila jarak antar kota dekat dan aman 
untuk melakukan perjalanan, akan banyak barang yang diipor sehingga ketersediaan barang akan melimpah, dan harga-harga akan turun" (Ibn Khaldun, 1967). Pandangan kedua tokoh ini, dalam teori ekonomi modern dikenal sebagai hukum permintaan dan penawaran.

Ajaran Islam menekankan terwujudnya keadilan dalam tatanan kehidupan masyarakat, baik yang bersifat mu'amalah maupun 'ibadah. Meskipun harga ditentukan oleh mekanisme pasar yang bertitik tolak pada kekuatan permintaan dan penawaran, namun keadilan tetap menjadi perhatian, misalnya mengenai harga yang adil. Diharamkannya riba, misalnya, merupakan upaya preventif untuk menjamin terciptanya harga yang adil. Istilah harga yang adil pada prinsipnya sudah ada sejak awal peradaban Islam. Ini, misalnya, dapat ditemukan dalam beberapa hadis Rasulullah saw. Istilah-istilah yang digunakan adalah qimah al-'adl, (Adiwarman A. Karim, 2006) atau tsaman al-mitsl. Di sini, Ibn Taimiyah memberikan penekanan tersendiri.

Ibn Taimiyah, tulis Karim, tampaknya merupkan orang pertama yang menaruh perhatian khusus terhadap permasalahan harga yang adil. Pendapat Karim ini, agaknya kurang tepat mengingat konsep justum pretium (harga yang adil), sebagaimana dijelaskan oleh Islahi (Islahi, 1997). Hanya saja, titik tekan dan inspirasi mengenai harga yang adil menjadi garis pembedanya. Dua istilah yang sering digunakannya adalah kompensasi yang setara ('iwadh al-mitsl) dan harga yang setara (tsaman almitsl). Kompensasi yang setara ('iwadh al-mitsl) diukur dan ditaksir oleh hal yang setara, dan ini merupakan esensi keadilan (nafs al-'adl). Kesetaraan adalah jumlah yang sama dari objek khusus dimaksud dala pemakaian yang umum ('urf). Hal ini juga berkaitan dengan tingkat harga (si'r) dan kebiasaan ('adah) (Adiwarman A. Karim, 2006). Lalu, apa yang dimaksud dengan harga yang setara (tsaman al-mitsl)? Dalam hal ini, Ibn Taimiyah membagi dua bentuk harga, yaitu: harga yang tidak adil dan dilarang; harga yang adil dan disukai (Ibn Taimiyah, 1982). Dari sini, dapat dipahami bahwa yang dimaksud dengan harga yang setara (tsaman almitsl) adalah harga yang adil dan disukai. Lebih tegas ditulisnya dalam Majmu' al-Fatawa:

"Harga yang setara adalah harga standar yang berlaku ketika masya- 
rakat menjual barang-barang dagangannya dan secara umum dapat diterima sebagai sesuatu yang setara bagi barang-barang tersebut atau barang-barang yang serupa pada waktu dan tempat yang khusus."

Jika dicerimati lebih dalam, maka perbedaan 'iwadh al-mitsl dan tsaman almitsl terletak pada aspek legal etik dan ekonomi. Sebagaimana ditegaskan Karim, 'iwadh al-mitsl berhubungan dengan sisi legal etik, sehingga ia berhubungan dengan, misalnya: kompensasi karena telah membahayakan orang lain, ganti rugi, merusak harta, dan lain sebagainya. Adapun tsaman al-mitsl berkaitan dengan persoalan ekonomi yang bertumpu pada kekuatan permintaan dan penawaran (Adiwarman A. Karim, 2006).

\section{Sistem Pasar Bebas (Neo-Liberalism)}

Sistem pasar bebas pada mulanya dikembangkan oleh Adam Smith dalam bukunya The Wealth of Nation. Setelah mengalami perkembangan dari bentuk klasik, neo-klasik, dan modern, kini sistem pasar bebas menjelma dalam istilah baru: neo-liberalism. Ini cukup beralasan mengingat doktrin Invisible Hand yang dikembangkan Adam Smith menitik beratkan pada kebebasan individu. Meskipun demikian, sementara pihak sedikit keliru dengan menganggap Adam Smith abai terhadap persoalan etika, karena ia sendiri menulis konsep etika pasar dalam bukunya Moral Sentiment (Priyono, 2007). Persoalan pandangan dunia budaya barat yang materialistis-liberal, agaknya tidak cukup signifikan dijadikan sebagai garis pembeda dengan ajaran Islam, karena sesungguhnya al-Qur'an sendiri sudah menegaskan bahwa manusia diberikan fitrah memiliki kegandrungan terhadap syahwat untuk memiliki materi, harta, wanita, alat transportasi, dan lainnya (Q.S. Ali ‘Imran [3]: 14). Bagaimana nilai-nilai etika dan moral dimanifestasikan dalam setiap aktifitas kehidupan merupakan asepk yang lebih penting dari hal itu.

Neoliberalisme dapat dipahami sebagai "a theory of political economic practices that proposes that human well-being can best be advanced by liberating individual entrepreneurial freedoms and skills within an institutional framework characterized by strong private property rights, free markets, and free trade (David Harvey, 2005). Peran negara adalah sebagai pihak yang mencipta- 
kan dan menjamin kerangka institusional yang mendukung dan sesuai dengan agenda neoliberalisme. Misalnya, jaminan atas stabilitas nilai mata uang, sehingga untuk tujuan tersebut harus didukung oleh kekuatan militer, pertahanan, kebijakan, dan hukum. Intervensi negara harus ditekan pada batas yang sangat minimum, karena menurut teori neoliberal, negara tidak mungkin bisa mendapatkan informasi yang cukup dari pelaku pasar untuk menentukan harga, dan kekuatan kepentingan suatu kelompok akan menciptakan distorsi dan intervensi negara yang bias (terlebih dalam negara demokrasi) hanya untuk keuntungan mereka (David Harvey, 2005).

Awalil Rizky dan Nasyith Majidi menjelaskan bahwa "neo-liberalisme merupakan konsep paling mutakhir dari kapitalisme, dalam arti yang mendominasi perwujudannya saat ini. Sebagai suatu aliran pemikiran, neoliberalisme memiliki akar pada gagasan kapitalisme awal" (Rizky dan Majidi, 2008; Erhard Eppler, 2009). Oleh sebab itu, sebagai sebuah agenda, terutama yang berkaitan dengan mekanisme dan sistem ekonomi, neoliberalisme baru dominan sekitar dua decade terakhir. Mengapa? Bentuk kapitalisme awal, terutama di Indonesia, adalah kolonialisasi fisik dan psikis. Institusi yang menjalankan fungsi ini pada era penjajahan dulu adalah VOC. Adapun sekarang, WTO, World Bank, IMF, dan beberapa lembaga internasional lainnya merupakan perwujudan dari "VOC" tersebut. Itulah sebabnya, neoliberalismejuga diselaraskan dengan neoimperealisme. Bentuknya adalah korporatokrasi. Berjingkraknya korupsi (terlebih dalam bentuk state capture corruption) adalah agenda neoimperalisme, tegas Amien Rais (2008).

Dengan demikian, sangat jelas sekali perbedaan antara mekanisme pasar dan sistem pasar bebas. Mekanisme pasar mengacu pada konsep tentang bagaimana harga tercipta berdasarkan kekuatan permintaan dan penawaran dan bisa dikatakan sunnatullah. Adapun sistem pasar bebas atau neoliberalisme merupakan kerangka dan sistem ekonomi dan ekonomi politik yang dirumuskan sebagai bentuk lanjut dari kapitalisme. Bahwa harga yang adil dalam suatu pasar sempurna tidak boleh diintervensi, merupakan sifat alamiah dari pasar tersebut. Akan tetapi, hal ini terlalu keliru dipahami sebagai doktrin kebebasan pasar (laissez 
faire stelsel), sehingga muncul pembenaran bahwa konsep pasar dari pemikiran Islam, pro terhadap sistem pasar bebas.

\section{Intervensi Pemerintah}

Untuk memahami pemikiran Ibn Taimiyah tentang intervensi pemerintah, maka terlebih dahulu dibahas bagaimana ia memahami negara, tujuan dan fungsi negara. Hal ini inheren dengan kerangka ekonomi politik (siyasah al-iqtishadiyah) yang dikembangkan oleh Ibn Taimiyah. Penting ditegaskan, memahami etika intervensi negara menurut pemikiran Ibn Taimiyah, tidak bisa dipahami dalam kerangka pro-kontra sistem pasar bebas. Karena Ibn Taimiyah menegaskan ada dua nilai dasar dalam penyelenggaraan negara, yaitu: amanah dan keadilan (Ibn Taimiyah, 1995). Dengan demikian, penyelenggaraan pasar haruslah dalam kerangka amanah dan keadilan.

\section{Negara: Tujuan dan Fungsinya}

Tema Agama dan Negara atau lebih khusus lagi Islam dan Negara, telah menyita banyak perhatian para sarjana. Di Indonesia, isu ini selalu menjadi "bola panas" mengingat tarik ulur hubungan Islam dan Negara yang sekalipun bersifat klasik dan cenderung repetisi, namun tidak kunjung usai (Effendy, 1998; Sjadzali, 1993; Thaba, 1996). Bahkan isu ini belakangan kembali hangat dengan adanya gerakan trans-nasional, ditambah tersebarnya hates-speech (kata-kata kebencian) seperti "sekularis, pluralis, liberalis" dan "islamis, fundamentalis, ekstrimis." Dalam hal ini, dan berkaitan dengan tema makalah ini, sangat menarik dielaborasi bagaimana pemikiran Ibn Taimiyah tentang negara: fungsi dan tujuannya.

Ibn Taimiyah, sebagaimana ditegaskan Arskal Salim, kurang tertarik dengan persoalan asal mula timbulnya negara. Pemikirannya tentang negara bersendikan pada ajaran agama, sebagaiman termaktub dalam surat an-Nisa, 58-59 (Sjadzali, 1993). Oleh sebab itu, bentuk dan susunan negara juga bukanlah fokus perhatiannya. Ini tampak dari pandangan Ibn Taimiyah tentang "wajibnya membentuk kepemimpinan". Yang terpenting bagi Ibn Taimiyah adalah pelaksanaan syari'ah atau dalam bahasa yang lain tegaknya amar ma'ruf nahi munkar. Akan tetapi, "Ibn 
Taimiyah ternyata tidak menjelaskan mekanisme kontrol yang efektif utuk mengawasi keselarasan dan kebijakan pemerintah." Oleh sebab itu, ia tidak memperkenankan rakyat melakukan pemberontakan sekalipun terhadap pemerintah yang zalim (Salim, 1999). Rakyat cukup tidak memberikan ketaatan kepada pemimpin seperti itu.

Tujuan negara (kekuasaan) menurut Ibn Taimiyah adalah "hanyalah unt uk kepentingan Allah semata dan agar kalimatullah dapat ditegakkan setinggi-tingginya. Sebab, Allah swt, sengaja menciptakan seluruh makhluk di dunia untuk kepentingan itu, dan untuk maksud tersebut Allah menurunkan kitab suci dan mengutus beberapa orang Rasul" (Ibn Taimiyah, 1982). Secara sederhana, dengan demikian dapat dipahami bahwa tujuan negara menurut Ibn Taimiyah adalah terlaksananya syari'at Islam di tengah kehidupan masyarakat. Oleh sebab itu, seseorang yang memangku jabatan negara berfungsi untuk merealisasikan tujuan tersebut. Dalam hal ini, Ibn Taimiyah menegaskan "seluruh kekuasaan Islam tujuanya adalah amar ma' ruf nahi munkar, baik yang bersifat makro, seperti perdana menteri, maupun mikro, seperti: badan kepolisian, kekuasaan kehakiman, dan kekuasaan fiscal dan kekuasaan hisbah (Ibn Taimiyah, 1982). Lebih rinci, Arskal Salim menyimpulkan ada lima macam fungsi negara dalam rangka menegakkan amar ma'ruf nahi munkar, yaitu: 1) Pelaksanaan dasar-dasar agama Islam; 2) Penegakan hukum/ keadilan dan perlindungan hak-hak; 3) Pemeliharaan ketertiban dan keseimbangan ekonomi; 4) Penyediaan infrastruktur sosial; 5) Pembelaan keamanan negara (Salim, 1999).

Untuk melaksanakan fungsi tersebut, khususnya yang berkaitan dengan pemeliharaan ketertiban dan keseimbangan ekonomi, negara memperoleh penerimaan kas yang berasal dari: ghanimah, sedekah, dan fai' (Ibn Taimiyah, 1995). Dari pemasukan tersebut, pemerintah mengalokasikannya untuk kepentingan rakyat, seperti: biaya pertahanan dan keamanan; gaji pembesar, pegawai negara, pelaksana tugas yudisial dan keagamaan; pembangunan sarana dan fasilitas umum; pembangunan sarana dan fasilitas penunjang pendidikan (Ibn Taimiyah, 1995). Penting dicatat, Ibn Taimiyah tidak mewajibkan sumber penerimaan dari zakat dibagikan secara merata kepada segenap mustahik zakat. Menurutnya, 
pembagian zakat tergantung pada tingkat kebutuhan dan kepentingan. Ibn Taimiyah merumuskan dua kriteria pembagian zakat, yaitu: 1) memenuhi kebutuhan umat Islam; dan 2) mendukung perjuangan Islam. dengan demikian, bila mustahik tidak memenuhi kriteria tersebut, maka tidak berhak menerima zakat, demikian dikutip Arskal Salim dalam Majmu' al-Fatawa (Salim, 1999).

\section{Regulasi Harga Pasar}

Sebagaimana telah disinggung, yang menjadi pokok penting bagi negara dalam melakukan fungsi pengawasan (hisbah) adalah basis etik, yaitu amanah dan keadilan. Di atas basis etik itu, negara menjamin kebebasan individu dalam melaksanakan aktifitas ekonomi, di samping juga berkewajiban menghilangkan kemiskinan, meregulasi pasar, merumuskan kebijakan moneter dan ekonomi yang pro-rakyat (Islahi, 1997). Pelanggaran terhadap prinsip etik tersebut merupakan perbuatan zulm, sehingga rakyat tidak harus mentaati pemerintah yang demikian.

Setidaknya, ada empat fungsi ekonomi muhtasib, yaitu: (1) memenuhi dan mencukup kebutuhan; (2) pengawasan terhadap industri; (3) pengawasan atas jasa; (4) pengawasan atas perdagangan (Islahi, 1997). Di samping melaksanakan empat fungsi tersebut, Ibn Taimiyah juga menambahkan bahwa muhtasib juga memiliki peran religius, seperti mengajak orang melaksanakan shalat jum'at, berkata jujur dan benar, menunaikan amanat, dan mencegah kemunkaran, seperti mengurangi takaran dan timbangan, penipuan dalam industri dan jual beli, dan lain sebagainya (Ibn Taimiyah, 1982).

Konsep harga adil yang digagas Ibn Taimiyah, juga tampak dalam sikapnya atas peran negara dalam meregulasi harga. Secara umum para ulama, termasuk Ibn Taimiyah menolak upaya penetapan harga oleh pemerintah. Karena hal tersebut merupakan perbuatan zulm yang melanggar hak-hak para pedagang dalam menentapkan harga. Di samping juga bisa mengakibatkan para pedagang enggan memasuki suatu negara karena harga barang dagangannya ditetapkan oleh pemerintah dan hal itu bisa merugikannya. Tegasnya, dalam kondisi normal tidak seorang pun yang boleh menetapkan harga. Akan tetapi, lain hal bila terjadi distorsi pasar. 
Terjadi perbedaan pendapat ulama tentang kebolehan pemerintah menetapkan harga. Ibn Taimiyah, dalam al-Hisbah memparkan perdebatan tersebut, kemudian menjelaskan pendapatnya (Ibn Taimiyah, 1982).

Dalam literature fiqh, penetapan harga secara paksa oleh pemerintah disebut dengan tas'ir al-jabari. Kata at-tas'ir berasal dari bahasa Arab yang berarti "penetapan harga". Sedangkan al-jabari berarti "secara paksa". Jika digabungkan tas'ir al-jabari berarti penetapan harga secara paksa. Dalam fikih Islam, ada dua istilah yang berbeda menyangkut harga suatu barang, yaitu as-saman dan $a s$-si'r. As-saman adalah patokan harga suatu barang, sedangkan $a s-s i^{\prime} r$ adalah harga yang berlaku secara aktual di pasar. Ulama fikih menyatakan bahwa fluktuasi harga suatu komoditas berkaitan erat dengan $a s$-si' $r$, bukan as-saman. Ulama fikih membagi $a s-s i^{\prime} r$ kepada dua macam. Pertama, harga yang berlaku alami, tanpa campur tangan pemerintah. Kedua, harga suatu komoditas yang ditetapkan oleh pemerintah setelah pertimbangan modal dan keuntungan bagi pedagang dan keadaan ekonomi masyarakat (Tim Penulis, 2006). Adanya perbedaan ulama dalam penetapan harga disebabkan perbedaan dalam memahami hadis Rasulullah saw. berikut:

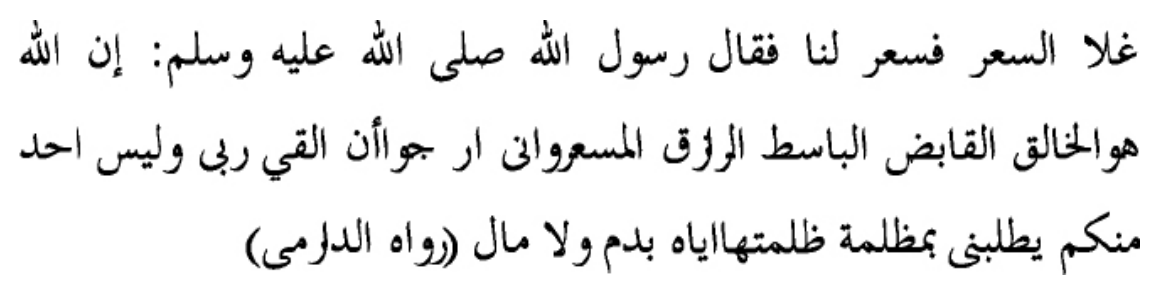

Harga melambung pada zaman Rasulullah SAW. Orang-orang ketika itu mengajukan saran kepada Rasulullah dengan berkata "Ya Rasulullah hendaklah engkau menentukan harga". Rasulullah SAW berkata: "Sesungguhnya Allah SWT lah yang menentukan harga, yang menahan dan melapangkan dan memberi rezki. Sangat aku harapkan bahwa kelak aku menemui Allah dalam keadaan tidak seorangpun dari kamu menuntutku tentang kezhaliman dalam darah maupun harta. (H.R. ad-Darimy)

Ibn Taimiyah menegaskan bahwa informasi yang diberikan hadis tersebut merupakan laporan bahwa seseorang tidak boleh menjual atau melakukan sesuatu yang wajib dilakukan atau menetapkan harga melebihi kompensasi yang ekuivalen ('iwād al-mithl) (Ishlahi, 1997). Alasan 
lainnya menurut Ibn Taimiyah adalah karena pada waktu itu, ada kelompok yang secara khusus hanya menjadi pedagang, di Madinah. Para penjual dan pedagang merupakan orang yang sama, satu sama lain (min jins wähid). Tak seorang pun bisa dipaksa untuk menjual sesuatu. Karena penjualnya tak bisa diidentifikasi secara khusus, kepada siapa penetapan harga itu akan dipaksakan. Terlebih lagi, menurut Ibn Taimiyah, barangbarang yang dijual di Madinah sebagain besar berasal dari impor. Kontrol apapun yang dilakukan atas barang itu akan menyebabkan timbulnya kekurangan suplai dan memperburuk situasi (Ishlahi, 1997). Kondisi ini tentunya meniscayakan Rasulullah untuk tidak menetapkan harga karena efek negatif yang ditimbulkan sangatlah besar.

Penetapan harga yang dilakukan oleh Rasulullah menurut Ibn Taimiyah terlihat pada waktu Rasulullah menetapkan harga yang adil, jika terjadi perselisihan antar dua orang. Kondisi pertama, dalam kasus pembebasan budaknya sendiri, Rasulullah mendekritkan bahwa harga yang adil (qimah al-adl) dari budak itu harus dipertimbangkan tanpa ada tambahan atau pengurangan (la wakasa wa la shatata), dan setiap orang harus diberi bagian dan budak harus dibebaskan. Kondisi kedua dilaporkan ketika terjadi perselisihan antar dua orang, satu pihak memiliki pohon yang sebagian tumbuh di tanah orang lain. Pemilik tanah menemukan adanya jejak langkah pemilik pohon di atas tanahnya yang dirasa mengganggunya. Ia mengajukan masalah itu kepada Rasulullah. Rasulullah memerintahkan pemilik pohon untuk menjual pohon itu kepada pemilik tanah dengan kompensasi atau ganti rugi yang adil kepadanya. Orang, itu, ternyata tidak melakukan apa-apa. Kemudian, Rasulullah membolehkan pemilik tanah untuk menebang pohon tersebut, dan ia memberikan kompensasi harganya kepada pemilik pohon (Ishlahi, 1997).

Secara garis besar, ada dua golongan dalam ranah ini. Golongan pertama melarang penetapan harga dalam kondisi atau komoditas apapun. Sebaliknya, golongan kedua yang membolehkan penetapan harga (Tim Penulis, 2006). Golongan pertama (ulama mazhab az-Zahiri, sebagian ulama mazhab Maliki, sebagian ulama mazhab Syafi'i, sebagian ulama mazhab Hanbali, dan Muhammad bin Ali asy-Saukāni) berpendapat bahwa dalam kondisi dan situasi apa pun, penetapan harga tidak 
dibenarkan, dan jika dilakukan maka hukumnya haram. Menurut mereka, baik harga itu melonjak naik disebabkan ulah para pedagang maupun disebabkan hukum alam, tanpa campur tangan pedagang, maka segala bentuk campur tangan dalam penetapan harga tidak dibolehkan. Alasan mereka adalah firman Allah SWT dalam surat an-Nisa' (4) ayat 29 yang menyatakan bahwa segala bentuk transaksi harus didasarkan kepada kerelaan hati kedua belah pihak. Keikutsertaan pemerintah dalam menetapkan harga menurut mereka akan menghilangkan unsur kerelaan tersebut. Ini berarti bahwa pemerintah telah melakukan perbuatan yang bertentangan dengan ayat al-Qur'an. Lebih lanjut, ulama fikih yang mengharamkan penetapkan harga ini mengatakan bahwa dalam sebuah transaksi ada pertentangan kepentingan, yaitu kepentingan konsumen dan kepentingan produsen. Pihak pemerintah tidak boleh memenangkan atau berpihak kepada satu pihak dengan mengorbankan pihak lain. Di sisi lain, jika penetapan harga diberlakukan, maka tidak mustahil para pedagang akan enggan menjual barang dagangannya. Bahkan tidak tertutup kemungkinan akan terjadi penimbunan barang oleh para pedagang karena harga yang ditetapkan tersebut tidak sesuai dengan keinginan mereka. Jika ini terjadi, pasar akan lebih kacau dan berbagai kepentingan akan terabaikan.

Golongan kedua (Ulama mazhab Hanafi, sebagian besar ulama Mazhab Hanbali seperti Ibn Taimiyah, Ibn Qayyim al-Jauziyah dan mayoritas pendapat ulama mazhab Maliki), membolehkan pihak pemerintah bertindak menetapkan harga yang adil (mempertimbangkan kepentingan pedagang dan pembeli), jika terjadi fluktuasi harga disebabkan ulah para pedagang. Alasan mereka adalah pemerintah dalam syari'at Islam berperan dan berwenang untuk mengatur kehidupan masyarakat demi tercapainya kemaslahatan mereka. Ibn Taimiyah dan Ibn Qayyim alJauziah, membagi bentuk penetapan harga itu kepada dua macam, yaitu: penetapan harga yang bersifat lalim, dan penetapan harga yang bersifat adil. Penetapan harga yang bersifat lalim adalah penetapan harga yang dilakukan oleh pemerintah tidak sesuai dengan keadaan pasar dan tanpa mempertimbangkan kemaslahatan para pedagang. Penetapan harga yang dibolehkan, bahkan diwajibkan adalah ketika terjadinya pelonjakan 
harga yang cukup tajam disebabkan ulah para pedagang. Untuk menetapkan harga, menurut Ibn Taimiyah pemerintah harus menyelenggarakan musyawarah dengan para tokoh perwakilan dari pasar (wujuh ahl al-suq). Setelah melakukan perundingan dan penyelidikan tentang jual beli, pemerintah secara persuasif harus menawarkan ketetapan harga yang didukung oleh peserta musyawarah, juga penduduk semuanya. Dengan kata lain, Ibn Taimiyah menegaskan bahwa penetapan harga tidak boleh dilakukan tanpa persetujuan dan izin mereka (Ishlahi, 1997).

Imam al-Ghazali (ahli fikih Mazhab Syafi'i) dengan menggunakan Qias Aulawi, mengqiaskan kebolehan penetapan harga dari pihak pemerintah ini kepada kebolehan pemerintah untuk mengambil harta orangorang kaya untuk memenuhi kebutuhan angkatan bersenjata, karena angkatan bersenjata berfungsi penting dalam pengamanan negara dan warganya. Menurut al-Ghazali, untuk kepentingan angkatan bersenjata harta orang-orang kaya boleh diambil tanpa imbalan, makan penetapan harga yang disebabkan ulah para pedagang lebih logis untuk dibolehkan, setelah memperhitungkan modal, biaya transportasi, dan keuntungan para pedagan tersebut.

Abu Yusuf (731-798 M), berpendapat segala kebijakansanaan penguasa harus mengacu kepada kemaslahatan warganya. Oleh sebab itu, jika pemerintah melihat bahwa piha pedagang telah melakukan manipulasi harga, pihak pemerintah boleh turun tangan untuk mengaturnya dan melakukan penetapan harga komoditas yang naik tersebut (Tim Penulis, 2006). Ibn Khaldun (1332-1383 M) dalam magnum opusnya Muqaddimah secara khusus membahas persoalah harga pada bagain "harga-harga di kota" (Ibn Khaldun, 2008). Namun, hasil analisis Muhammad Abdul Mun'im ak-Jamal, terhadap teori harga Ibn Khaldun mengatakan bahwa Ia secara spesifik tidak mofokuskan pembahasan terhadap penetapan harga, namun Ibn Khaldun menurutnya lebih menekan kepada aspek penyebab terjadinya fluktuasi harga di pasar (Muhammad Abdul Mun'im al-Jamal, 1992; Adiwarman A. Karim, 2007). Hal ini memperlihatkan bahwa Ibn Khaldun lebih bertendensi terhadap terbentuknya pasar sempurna secara ideal, walaupun tetap mengakui peran pemerintah dalam regulasi harga tersebut. Regulasi pemerintah dalam perspektif Ibn Khaldun ini agak- 
nya cendrung kepada upaya pengawasan terhadap prilaku masyarakat di pasar.

\section{Kesimpulan}

Berdasarkan pemaparan dan analisis atas pemikiran Ibn Taimiyah, dapat dipahami bahwa pemikiran Ibn Taimiyah sangat dipengaruhi oleh struksi sosial masyarakat, politk, ekonomi, dan hukum pada masa kehidupannya, sehingga tidak bisa dikatakan murni dipengaruhi oleh teksteks ajaran Islam. Oleh sebab itu, berkaitan dengan intervensi negara pemikirannya tidak bisa dikategorikan secara simplifikasi berpihak kepada sistem walfare state kaum sosialis, atau sistem pasar bebas yang diusung kelompok kapitalisme-liberalisme. Intervensi negara dilakukan hanya pada posisi mendesak dan kondisi sosial ekonomi menghendakinya. Ini dikarena negara merupakan instrumen untuk merealisasikan penegakan syari'at Islam. Namun, yang terpenting adalah semua itu haruslah berpijak pada landasan etis, yaitu: amanah dan keadilan. Dengan demikian, sistem pasar bebas islami sesungguhnya konsepsi yang mustahil terwujud, terlebih dalam struktur ekonomi pasar bebas yang dimainkan oleh korporatokrasi dunia. Dengan kata lain, doktrin sistem ekonomi pasar bebas, jelas-jelas bertentangan dengan nilai etika dasar penyelenggaraan negara yang dalam teori Abu Yusuf disimpulkan dalam satu kaidah: tasarrufal-imam 'ala al-ra'iyah manutun bi al-maslahah (kebijakan pemerintah dalam mengurus persoalan umat, haruslah bertujuan untuk mewujudkan kemaslahatan). Wallahu a'lam bi al-shawab.

\section{Daftar Pustaka}

Ad-Darimy, Imam. tt. Sunan ad-Darimy. Beirut: Darul Fikr. Jilid 2.

Al-Jamal, Muhammad Abdul Mun'im. 1992. Mawsu'at al-Iqtishad al-Islami.

Diterjemahkan oleh Salahuddin Abdullah dengan Ensiklopedi

Ekonomi Islam. Malaysia: Dewan Bahasa dan Pustaka Jilid 2. Cet. 2. Amalia, Euis. 2010. Sejarah Pemikiran Ekonomi Islam. Jakarta: Gramata 
Publishing.

Amitai-Preiss, Reuven. 1996. "Ghazan, Islam and Mongol Tradition: A View from the Mamlūk Sultanate," dalam Bulletin of the School of Oriental and African Studies. University of London. Vol. 59 No. 1.

Armstrong, Karen. 2002. Islam a Short History. New York: Modern Library. Berkey, Jonathan P. 2004. “The Muhtasib's of Cairo Under the Mamluks: Toward an Understanding of an Islamic Institution," dalam Michael Winter and Amalia Levanoni, The Mamluks in Egyptian and Syrian Politics and Society. Boston: Brill.

Effendy, Bahtiar. 1998. Islam dan Negara Transformasi Pemikiran dan Praktik Politik Islam di Indonesia, Jakarta: Paramadina.

El-Ashker, Ahmed, and Rodney Wilson. 2006. Islamic Economic a Short History, Leiden-Boston, Brill,

Eppler, Erhard, Melindungi Negara dari Ancaman Neoliberal, terj. Jakarta: Friedrich-Ebert-Stiftung, 2009

Harvey, David, A Brief History of Neoliberalism, New York: Oxford University Press, 2005

Hoetoro, Arif, Ekonomi Islam Pengantar Analisis Kesejarahan dan Metodologi, Malang: BPFE Universitas Brawijaya, 2007

Islahi, Abdul Azim, Contribution of Muslim Scholars to Economic Thought and Analysis, Jeddah: King Abdulazis University, 2005 - Economic Concepts of Ibn Taimiyah, London: The Islamic Foundation, 1988 Konsepsi Ekonomi Ibn Taimiyah, terj. Surabaya: Bina Ilmu, 1997 Karim, Adiwarman A., Ekonomi Mikro Islam, Edisi 3, Jakarta: Raja Grafindo Persada, 2007 Sejarah Pemikiran Ekonomi Islam, Edisi Ketiga, Jakarta: Rajawali Press, 2006

Karim, Muhammad Abdul, Islam di Asia Tengah: Sejarah Dinasti MongolIslam, Yogyakarta: Bagaskara, 2006

Khaldun, Ibn, Muqaddimah, alih bahasa, Ahmadie Thoha, Cet. 8 Jakarta Pustaka Firdaus, 2008 
Muqaddimah, English Edition, translated by Franz Rosenthal, London: Routledge \& Kegan Paul, 1967

Meloy, Jhon L., "The Merits of Economic History: Re-Reading al-Maqrizi's Ighathah and Shudhur," Mamluk Studies Review Vol. 7/2, 2003.

Priyono, B. Herry, "Adam Smith dan Munculnya Ekonomi: Dari Filsafat Moral ke Ilmu Sosial," Diskursus, Vol. 6, No. 1, April 2007

Rahardja, Pratama, dan Mandala Manurung, Teori Ekonomi Mikro Suatu Pengantar, Jakarta: LPFEUI, 1999

Rais, Mohammad Amien, Agenda-Mendesak Bangsa Selamatkan Indonesia!, Yogyakarta: PPSK, 2008

Rizky, Awalil, \& Nasyith Majidi, Neoliberalisme Mencengkram Indonesia, Jakarta: E. Publishing, 2008

S.M. Ghazanfar (Ed.), Medieval Islamic Economic Thought; Filling the Great Gap in European Economics, London \& New York: Routledge, 2003

Salim, M. Arskal, Etika Intervensi Negara Perspektif Etika Politik Ibnu Taimiyah, Jakarta: Logos, 1999

Schultz, Warren C., "The Circulation of Dirham in the Bahri Period," dalam Michael Winter and Amalia Levanoni, The Mamluks in Egyptian and Syrian Politics and Society, Leiden. Boston: Brill, 2004

Schumpeter, Joseph A., History of Economic Analysis, New York: Oxford Universiy Press, 1954

Sjadzali, Munawir, Islam dan Tata Negara: Ajaran, Sejarah, dan Pemikiran, Jakarta: UI Press, 1993

Stiglitz, Joseph E., \& Carl E. Walsh, Economics, New York: W.W. Norton \& Company, 2005

Stuart-Fox, Martin, A History of China and Southeast Asia: Tribute, Trade, and Influence, Australia: Allen \& Unwin, 2003

Taimiyah, Ibn, al-Siyasah al-Syar'iyyah fi Islah al-Ra'i wa al-Ra'iyyah, Bairut: Dar al-Afaq al-Jadidah, 1983

, Siyasah Syar'iyah, Etika Politik Islam, terj. Surabaya: Risalah Gusti, 1995 
Public Duties in Islam: The Institution of the Hisba, terj. UK: The Islamic Foundation, 1982

Thaba, Abdul Azis, Islam dan Negara dalam Politik Orde Baru, Jakarta: Gema Insani Press, 1996

Tim Penulis, Ensiklopedi Hukum Islam, Jakarta: Ikhtiar Baru van Heove, 2006 